\title{
Development of mycorrhizal infection in in vitro- and in vivo-formed roots of woody fruit plants
}

\author{
I Gribaudo ${ }^{1 *}$, R Zanetti ${ }^{2}$, MA Morte ${ }^{2}$, A Previati ${ }^{3}$, A Schubert 2 \\ 1 Centro Miglioramento Genetico e Biologia Vite, CNR, Via Leonardo da Vinci 44, 1-10095 Grugliasco (To); \\ 2 Dipartimento Colture Arboree dell'Università, Torino; \\ ${ }^{3}$ ESAV Azienda Sperimentale Po di Tramontana, Rosolina (RO), Italy
}

(Received 30 July 1996; accepted 23 September 1996)

\begin{abstract}
Summary - Micropropagated shoots of grapevine (Vitis berlandieri $\times V$ riparia Kober $5 \mathrm{BB}$ ), kiwifruit (Actinidia deliciosa cv Hayward) and apple (Malus pumila MM106) were rooted in media containing a vital staining in order to distinguish in vitro-formed from in vivo-formed roots. Presence of the dye reduced plant growth in apple only. At transfer into the soil, plants were inoculated with the arbuscular mycorrhizal fungus Glomus mosseae. The dye did not prevent root colonization by the mycorrhizal fungus. After 4 to 5 weeks from transplant both in vitro- and in vivo-formed roots were colonized by the arbuscular mycorrhizal fungus.
\end{abstract}

\section{VA mycorrhiza / kiwifruit / grapevine / apple / micropropagation}

Résumé - Développement de l'infection mycorhizienne dans des racines formées in vitro et in vivo de plants fruitiers. Des vitroplants de vigne (Vitis berlandieri x V riparia Kober $5 \mathrm{BB}$ ), de kiwi (Actinidia deliciosa 'Hayward') et de pommier (Malus pumila MM106) ont été produits dans des milieux gélosés contenant un colorant vital pour différencier, après transplantation dans le sol, les racines développées in vitro de celles in vivo. La présence du colorant a réduit la croissance des plantes seulement dans le cas du pommier. Les vitroplants ont été inoculés, lors de la transplantation dans le sol, avec des spores du champignon mycorhizogène à arbuscules Glomus mosseae. La coloration des racines n'a pas empêché le développement de l'infection racinaire : aussi bien les racines développées in vitro que celles in vivo étaient mycorhizées après 4 à 5 semaines.

mycorhize arbusculaire / kiwi / vigne / pommier / micropropagation

* Correspondence and reprints 


\section{INTRODUCTION}

Acclimatization of micropropagated plants is more successful if the in vitro-formed root system is able to efficiently support the plant during hardening and growth after transplant. According to some authors, in vitro-formed roots degenerate and are mostly replaced by new roots during acclimatization (Maene and Debergh, 1983; McClelland et al, 1990); on the contrary, their survival after transfer to soil has been observed in Asian jasmine (Apter et al, 1993). In micropropagated grapevine, addition of the dye gentian violet to the rooting medium made it possible to distinguish between in vitro- and in vivoformed root segments after acclimatization (Gribaudo et al, 1995): up to $80 \%$ of in vitro-originated roots survived the acclimatization phase. Gentian violet (crystal violet, methyl violet, basic violet 3 ) is a water-soluble, cationic triarylmethane dye with low or no toxic effects on plants at low concentration (Kaufmann, 1968; Arnold and Young, 1990).

The aim of this research was to assess i) the efficacy of the staining system on different woody fruit species and ii) the capability of in vitro- and in vivo-formed roots to establish mycorrhizal symbiosis.

\section{MATERIALS AND METHODS}

Three species were used in these experiments: the grapevine rootstock Kober 5 BB (Vitis berlandieri $x$ $\checkmark$ riparia), kiwifruit (Actinidia deliciosa cv Hayward) and the apple rootstock MM106 (Malus pumila). Rooting media were i) Murashige and Skoog (1962) modified as indicated by Gribaudo et al (1995) for grapevine and kiwifruit, and ii) Murashige and Skoog with $5 \mu \mathrm{M}$ indolebutyric acid (IBA) for apple; $0.15 \mathrm{mg}^{-L^{-1}}$ gentian violet (sterile-filtered acqueous solution; Fluka Chemie $A G$, Switzerland) were added to the rooting media immediately after autoclaving at $120^{\circ} \mathrm{C}$ for $10 \mathrm{~min}$.

Shoots were excised from stock plants and cultured on the staining media or on a dye-free medium (control) for 3 (grapevine and kiwifruit) or 4 (apple) weeks. Cultures were kept in a culture chamber at $24{ }^{\circ} \mathrm{C}$ and $35 \mu \mathrm{mol} \mathrm{m}-2 \mathrm{~s}^{-1}$ photosynthetic photon flux (PPF), $16 \mathrm{~h}$ photoperiod. Results were analyzed using the analysis of variance (ANOVA) test.

Rooted plantlets were transferred to a sterilized 1:1 mixture of soil $(\mathrm{pH} \mathrm{7.4)}$ and sand under a plastic tent, and acclimatized by gradually opening the tent during a 2-week period. Half of the plants were inoculated with the arbuscular mycorrhizal (AM) fungus Glomus mosseae (Nicol and Gerd) Gerdemann and Trappe (BEG12), adding $1.5 \mathrm{~g}$ of inoculum to each $250 \mathrm{~mL}$ pot (= 20 propagules; Porter, 1979) at transplant. After 4 (kiwifruit) or 5 (grapevine) weeks, the plants were collected and the roots were cut and divided, according to the origin, into three groups: i) the basal part of old roots, ie root segments formed in vitro; ii) the apical part of old roots, which was formed after transfer to the soil (in vivo); iii) new roots entirely formed after transfer to the soil (in vivo).

For plants rooted on staining media, collected roots were assigned to a group on the basis of the colour of the roots themselves. For plants rooted in absence of the stain, roots were assigned to a group on the basis of the measurements (root number, length and position on the stem base) taken at the transplant.

Table I. Shoot length and root number and length of micropropagated kiwifruit cv Hayward and apple rootstock MM106 rooted on media containing 0 or $0.15 \mathrm{mg}^{\bullet} \mathrm{L}^{-1}$ gentian violet (30 kiwifruit and 60 apple plants/treatment).

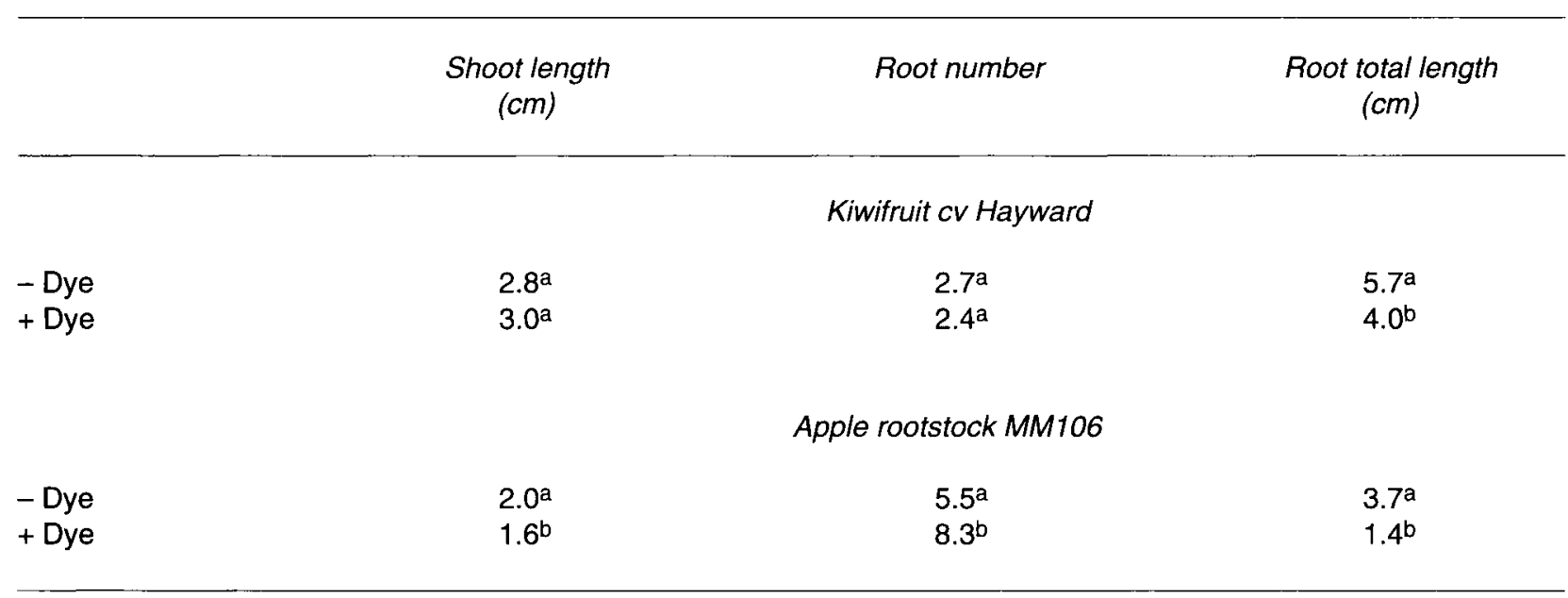

ab For each treatment and species, values followed by the same letter do not differ significantly at $P=0.01$. 
Table II. Mycorrhization percentages of the three types of roots or root segments, after 4 (kiwifruit) or 5 (grapevine) weeks from the transfer to soil.

$+D y e+A M$ fungus $-D y e+A M$ fungus + Dye - AM fungus -Dye-AM fungus

Grapevine Kober 5BB

In vitro-formed segments of old roots In vivo-formed segments of old roots New roots formed entirely in vivo
43

60

60
37

45

75
0

$0 \quad 0$

\section{Kiwifruit cv Hayward}

In vitro-formed segments of old roots In vivo-formed segments of old roots New roots formed entirely in vivo
30

60

40
20

40

50
0

$0 \quad 0$

The dye gentian violet $\left(0.15 \mathrm{mg}^{\circ} \mathrm{L}^{-1}\right)$ was added to the rooting medium during in vitro culture. Glomus mosseae was inoculated at the transfer to soil (six grapevine and eight kiwifruit plants/treatment).

\section{RESULTS}

In kiwifruit the presence of $0.15 \mathrm{mg}\left\llcorner^{-1}\right.$ gentian violet did not affect shoot growth and root number but slightly reduced root length (table I) after 3 weeks of culture in the rooting medium. Afterwards, plants were acclimatized and after 4 weeks in the soil no more significant differences were found between plants with stained roots and controls (data not shown).

In apple the dye initially reduced plant height and root length but increased root number.

In grapevine and kiwifruit, the dye in the rooting medium made the in vitro-formed roots easily recognizable after 4 or 5 weeks in soil. In contrast, in apple this dye concentration was insufficient to distinguish in vitro- and in vivo-formed roots after 4 weeks of culture in soil. The number of roots was too elevated to discriminate them on the basis of measurements taken at transplant. Consequently, AM infection of the various root types was assessed on grapevine and kiwifruit only.

In grapevine, in vitro-formed roots usually have a smaller diameter compared to in vivoformed ones, as previously observed (Gribaudo et al, 1995).

All types of roots were colonized by the AM fungus, both in grapevine and in kiwifruit (table II). The presence of gentian violet in the rooting medium did not prevent root colonization by the AM fungus.

\section{CONCLUSION}

The effect of gentian violet was previously evaluated on Kober 5BB, by adding 0.15 and $0.3 \mathrm{mg}^{\circ} \mathrm{L}^{-1}$ to the rooting medium (Gribaudo et al, 1995). Based on those results, only the lowest dye concentration $\left(0.15 \mathrm{mg}^{\circ} \mathrm{L}^{-1}\right)$ was used in this experiment. The effects of dye on kiwifruit plant growth were similar to those reported for grapevine (Gribaudo et al, 1995) and Asian jasmine (Apter et al, 1993). Apple plantlets showed a different feature: in apple the dye induced a growth reduction, and the concentration used did not allow to individuate in vitro-formed roots after 4 weeks in soil. Solutions to this problem could be a shorter period in soil or higher stain concentration, although the latter could further depress root growth.

In grapevine and kiwifruit the use of the dye gentian violet at the concentration of $0.15 \mathrm{~g}^{\circ} \mathrm{L}^{-1}$ in the rooting media confirmed its usefulness as a method for easy identification of in vitro-formed roots after acclimatization. The slight growth reduction effect weakens in the long run. Moreover, AM root colonization was not prevented by the dye.

In grapevine and kiwifruit, both in vitro- and in vivo-formed roots were colonized by the AM fungus Glomus mosseae. Our results show that in vitro-formed roots can'successfully establish AM infection after transfer to soil. 


\section{ACKNOWLEDGMENTS}

A Morte acknowledges a grant from the Spanish Ministerio de Educacion y Ciencia.

\section{REFERENCES}

Apter RC, Davies FT Jr, McWilliams E (1993) In vitro and ex vitro adventitious root formation in Asian Jasmine (Trachelospermum asiaticum). II. Physiological comparisons. J Am Soc Hort Sci 118, 906-909

Arnold MA, Young E (1990) Use of dye to facilitate measurement of new root growth of apple. Hort Sci $25,116-118$

Gribaudo I, Morte AM, Schubert A (1995) Use of gentian violet to differentiate in vitro- and ex vitro- formed roots during acclimatization of grapevine. Plant Cell Tiss Org Cult 41, 187-188

Kaufmann MR (1968) Water relations of pine seedlings in relation to root and shoot growth. Plant Physiol $43,281-288$

Maene LM, Debergh PC (1983) Rooting of tissue-cultured plants under in vitro conditions. Acta Hort 131, 201-208

McClelland MT, Smith MAL, Carothers ZB (1990) The effects of in vitro end ex vitro root initiation on subsequent microcutting root quality in three woody plants. Plant Cell Tiss Org Cult 23, 115-123

Murashige T, Skoog F (1962) A revised medium for rapid growth and bioassay with tobacco tissue culture. Physiol Plant 15, 473-497

Porter WM (1979) The 'most probable number' method for enumerating infective propagules of vesiculararbuscular mychorrizal fungi. Aust $J$ Soil Res 17, 515-519 